\title{
Behavior of Copper, Nickel, Cadmium and Mercury Ions in Anode Chamber of Microbial Fuel Cells
}

\author{
Ruizhe Gai, Yiyang Liu, Jie Liu, Chi Yan, Yang Jiao, Lankun Cai, Lehua Zhang* \\ State Environmental Protection Key Laboratory of Environmental Risk Assessment and Control on \\ Chemical Process, School of Resources and Environmental Engineering, East China University of \\ Science and Technology, Shanghai 200237, China \\ *E-mail: lezhanghua@ecust.edu.cn
}

doi: $10.20964 / 2018.03 .69$

Received: 19 April 2017 / Accepted: 7 June 2017 / Published: 5 February 2018

\begin{abstract}
Microbial fuel cell (MFC) technology is widely used in wastewater treatment, and heavy metal ions play a important role in MFCs. In this paper, we studied the effect of heavy metal ions (copper, nickel, cadmium and mercury) on anode, mainly in voltage output and the recovery after feeding with high concentration of those heavy metal ions. It was concluded that anolyte containing low concentration of $\mathrm{Cu}^{2+}$ and $\mathrm{Ni}^{2+}$ can improved the performance of MFCs, but when the concentration become higher, the voltage outputs decreased, the minimum toxic concentration of $\mathrm{Cu}^{2+}$ is $303 \mu \mathrm{mol} / \mathrm{L}$ and $\mathrm{Ni}^{2+9} \mathrm{~s}$ is 600 $\mu \mathrm{mol} / \mathrm{L}$. As for $\mathrm{Cd}^{2+}$ and $\mathrm{Hg}^{2+}$, the voltage outputs decreased once these ions added into the MFCs. After replaced the anodic solution with a refresh solution that containing no heavy metal ions, the MFCs would recover in several hours $\left(\mathrm{Cu}^{2+}, \mathrm{Ni}^{2+}\right.$ and $\mathrm{Cd}^{2+}$ in $24 \mathrm{~h}, \mathrm{Hg}^{2+}$ in $\left.30 \mathrm{~min}\right)$.
\end{abstract}

Keywords: Microbial fuel cells; Voltage output; Anode; Metal ions

\section{FULL TEXT}

(C) 2018 The Authors. Published by ESG (www.electrochemsci.org). This article is an open access article distributed under the terms and conditions of the Creative Commons Attribution license (http://creativecommons.org/licenses/by/4.0/). 